\title{
Przedsiębiorczość i innowacyjność akademicka w Polsce
}

\author{
Academic Entrepreneurship and Innovation in Poland
}

Streszczenie: Celem zmian w strukturze szkolnictwa wyższego w Polsce powinno być uruchomienie mechanizmów konkurencyjności, a zasadniczym podmiotem procesu zmian jest przedsiębiorczy uniwersytet. Powstanie przedsiębiorczego uniwersytetu daje szansę społeczności akademickiej na komercjalizację badań naukowych. Bez znaczącego wzrostu innowacji przedsiębiorczość akademicka będzie uwięziona w stagnacji. Jednak przestawienie przedsiębiorczości akademickiej na tory innowacyjności jest bardzo trudnym zadaniem, ponieważ środowisko akademickie charakteryzuje bardzo niski poziom przedsiębiorczości. Zmiany w funkcjonowaniu wyższych uczelni w Polsce zachodzą powoli i są opóźniane przez tradycyjne, biurokratyczne struktury organizacyjne uczelni, niechęć władz uczelni do stosowania elastycznych metod zarządzania oraz brak rynkowych instrumentów wsparcia przedsiębiorczości akademickiej. Narzędziem pobudzania przedsiębiorczości akademickiej jest tworzenie warunków do rozwoju i wspieranie innowacyjnych przedsiębiorstw typu spin-off oraz spin-out. Innowacyjne akademickie przedsiębiorstwa wymagają znaczących nakładów inwestycyjnych, których zwrot obarczony jest bardzo wysokim ryzykiem. Jest to jedna z przyczyn spowolnienia procesu rozwoju innowacyjności akademickiej. Celem głównym niniejszego opracowania była ocena poziomu efektywności zarządzania uniwersytetem przez wskazanie, w jaki sposób lepiej niż dotychczas wykorzystać największą wartość uczelni, którą są jej pracownicy, studenci i absolwenci oraz posiadana przez nich wiedza. Dla zapewnienia właściwej realizacji celu głównego sformułowano również cele szczegółowe. Realizacja postawionych w pracy celów wymagała rozwiązania kilku problemów badawczych. Głównym problemem stała się ocena poziomu efektywności organizacyjnej uniwersytetów przez porównanie do najlepszych (benchmarking wyników). Wiązało się to ze stworzeniem modelu zarządzania uniwersytetem i określeniem, jakie wymiary i kryteria powinien tworzyć model zapewniający ocenę efektywności organizacyjnej. Należało wskazać kluczowe czynniki w efektywności organizacyjnej (kosztowej i finansowej). Istotnym elementem przy ocenie efektywności organizacyjnej było również nakreślenie obszarów efektywności i kryteriów przyjętych do stosowania.

\footnotetext{
Abstract: the aim of changes in the structure of higher education in Poland should be encouraging competitiveness processes, and the essence of changes is creating an entrepreneurial university. The creation of an entrepreneurial university gives the academic community the possibility of commercialisation of research. Without a significant increase in innovation, academic entrepreneurship will be trapped in stagnation. Focusing academic entrepreneurship on innovation is a very difficult task, because the academic environment is characterised by a very low level of entrepreneurship. Changes in the functioning of institutions of higher education in Poland occur at a slow pace and are even further delayed by the traditional bureaucratic structure of the university, the university authorities reluctance to use flexible
} 
methods of management, lack of market instruments to support academic entrepreneurship. A tool for stimulating academic entrepreneurship is to create conditions for the development and support of innovative spin-off and spin-out business. Innovative academic enterprises require significant capital investment whose return is burdened with very high risk. This is one of the reasons for the slowdown of the process of innovation development of academia. The main aim of the study is to assess the level of university management effectiveness by showing how the highest value of the university, its employees, students, graduates and their knowledge, is better than ever before. In order to ensure proper fulfillment of the main objective, specific objectives have also been formulated. Implementing the objectives of the study requires addressing several research problems. The main problem is to assess the level of organizational efficiency of universities by comparing to the best (benchmarking results). This involves creating a model for managing the university and determining what dimensions and criteria should be created for a model that evaluates organisational effectiveness. Key factors in organisational effectiveness (cost and financial) had to be defined. It is also important to evaluate the effectiveness of the organisation and the criteria adopted for the evaluation of organisational effectiveness.

Słowa kluczowe: innowacyjność akademicka; przedsiębiorczość; przedsiębiorczy uniwersytet; przedsiębiorstwa spin-off; start-upy;

Keywords: academic innovation; entrepreneurial university; entrepreneurship spin-off enterprises; startups

Otrzymano: 19 listopada 2016

Received: 19 November 2016

Zaakceptowano: 30 czerwca 2017

Accepted: 30 June 2017

\section{Sugerowana cytacja/Suggested citation:}

Makieła, Z. (2017). Przedsiębiorczość i innowacyjność akademicka w Polsce. Przedsiębiorczość Edukacja [Entrepreneurship - Education], 13, 183-195. DOI: 10.24917/20833296.13.13

\section{Wstęp}

„Innowacyjność gospodarki każdego kraju jest ściśle powiązana z poziomem i dynamiką rozwoju nauki i edukacji. Im wyższy poziom rozwoju szkolnictwa, tym wyższe miejsce w poziomie innowacyjności zajmuje dane państwo, bez względu na to, na jakie rankingi się powołujemy. W globalnym rankingu innowacyjności państw w 2015 roku sporządzonym przez ekspertów z Uniwersytetu Cornella Polska zajęła 39 miejsce; najwyżej, na 32 miejscu, oceniono uwarunkowania instytucjonalne innowacyjności w naszym kraju (polityka ekonomiczna, regulacje środowiska, otoczenie biznesu), a dopiero na 68 miejscu - wpływ wiedzy na rozwój gospodarczy (PNB). Wśród czynników determinujących poziom i dynamikę innowacyjności najsilniejszych gospodarczo państw świata poczesne miejsce zajmują efekty funkcjonowania edukacji i nauki, zwłaszcza szkolnictwa wyższego w tych krajach, bez których nie ma rozwoju innowacji. Jedynym sposobem na budowę prawdziwie innowacyjnej gospodarki jest skonstruowanie pomostu między światem nauki a biznesu, które oddziela tzw. dolina śmierci” (Wawak, 2017: 7).

Przedsiębiorczość i innowacyjność akademicka w Polsce, rozumiane jako nowa forma aktywności środowiska wyższych uczelni, są przedmiotem dyskusji o nowym modelu funkcjonowania uczelni w warunkach globalizacji. „Przedsiębiorczość akademicka jest specyficznym rodzajem przedsiębiorczości, koncentrującym się na kreatywnych postawach środowiska naukowego i wykorzystaniu ich efektów w praktyce gospodarczej” 
(Poznańska, 2014). Celem dyskusji na temat przedsiębiorczości i innowacyjności akademickiej jest to, czy działania uczelni wyższych, jej pracowników naukowych, doktorantów, studentów, absolwentów, mają na celu komercjalizację wyników ich badań naukowych, czyli praktycznego wykorzystania dorobku naukowego w biznesie. Taki wniosek dotyczący konieczności współpracy tych środowisk wynika z wymiany opinii między wszystkimi uczestnikami a beneficjentami proinnowacyjnych działań w naszym kraju. Ich zdaniem ma to służyć do wypracowania konkretnych rozwiązań współpracy nauki $\mathrm{z}$ gospodarką, przyspieszających proces transformacji polskiej gospodarki w kierunku modelu innowacyjnego. Proces ten został zapoczątkowany i wzmocniony ustawą Prawo o szkolnictwie wyższym ${ }^{1}$, w której przedsiębiorczość akademicka jest regulowana prawnie. Już w artykule 4 ust. 4 tej ustawy czytamy: „Uczelnie współpracują z otoczeniem społeczno-gospodarczym, w szczególności w zakresie prowadzenia badań naukowych i prac rozwojowych na rzecz podmiotów gospodarczych, w wyodrębnionych formach działalności, w tym w drodze utworzenia spółki celowej, o której mowa w art. 86a, a także przez udział przedstawicieli pracodawców w opracowywaniu programów kształcenia i w procesie dydaktycznym" (Enders, Musselin, 2008: 18).

Celem głównym niniejszego opracowania stała się ocena poziomu efektywności zarządzania uniwersytetem przez wskazanie, w jaki sposób lepiej niż dotychczas wykorzystać największą wartość uczelni, którą stanowią jej pracownicy, studenci i absolwenci oraz posiadana przez nich wiedza.

Dla zapewnienia właściwej realizacji celu głównego sformułowano również cele szczegółowe:

- wskazanie na konieczność dyskusji i refleksji nad funkcjonowaniem uczelni, nad wdrażaniem zmian, których zadaniem jest aktywność innowacyjna środowiska akademickiego,

- uruchomienie procesu komercjalizacji badań naukowych,

- wzmocnienie pozycji konkurencyjnej polskich uczelni na tle innowacyjnych uczelni w skali globalnej.

Realizacja postawionych w pracy celów wymagała rozwiązania kilku problemów badawczych. Głównym problemem stała się ocena poziomu efektywności organizacyjnej uniwersytetów przez porównanie do najlepszych (benchmarking wyników). Wiązało się to ze stworzeniem modelu zarządzania uniwersytetem i określeniem, jakie wymiary i kryteria powinien tworzyć model zapewniający ocenę efektywności organizacyjnej. Należało wskazać kluczowe czynniki w efektywności organizacyjnej (kosztowej i finansowej). Istotnym elementem przy ocenie efektywności organizacyjnej było również nakreślenie obszarów efektywności i kryteriów przyjętych do stosowania.

\section{Uniwersytet przedsiębiorczy/innowacyjny, uniwersytet uczący się}

Refleksje nad zachodzącymi zmianami uniwersytetu jako szkoły wyższej o charakterze akademickim obejmują wiele poziomów, np. skutki powszechnego dostępu do studiów wyższych, niskiego poziomu wiedzy absolwentów szkół średnich, zróżnicowanego poziomu kształcenia w szkołach wyższych, a także zapewnienie wysokiej jakości kształcenia, dostosowanie ofert kształcenia do rynku pracy, niedobory finansowania nauki,

\footnotetext{
${ }^{1}$ Ustawa Prawo o szkolnictwie wyższym z dnia 27 lipca 2005 r. (Dz.U. Nr 164, poz. 1365, z późn. zm).
} 
ograniczenie patologii w procesie awansu naukowego itp. Kierunek dyskusji dotyczy w mniejszym stopniu istoty zmian samej szkoły wyższej o charakterze akademickim. Zmiana wizerunku uczelni jest niejednoznacznie oceniana przez znaczną część środowiska naukowego. Zaniepokojenie budzi także pogarszająca się ocena szkół wyższych przez odbiorców usług edukacyjnych. Spowodowane jest to m.in. niewłaściwym nadzorem nad funkcjonowaniem niektórych uczelni publicznych i niepublicznych oraz nieprzestrzeganiem procedur formalno-prawnych w tych szkołach wyższych (Wawak, 2012). Elementem dyskusji nad funkcjonowaniem szkoły wyższej jest również to, w jaki sposób lepiej niż dotychczas wykorzystać największą wartość uczelni, którą stanowią jej pracownicy, studenci, absolwenci oraz posiadana przez nich wiedza. Pod wpływem wyzwań współczesnego świata i gospodarki opartej na wiedzy istnieje przekonanie o potrzebie tworzenia uniwersytetu trzeciej generacji (Wisseman, 2005), uniwersytetu przedsiębiorczego/innowacyjnego (Andrzejczak, 2015).

W kontekście rozważań nad uniwersytetem przedsiębiorczym/innowacyjnym, uniwersytetem uczącym się, należy postawić hipotezę: Czy uniwersytet/szkoła wyższa to swoiste przedsiębiorstwo, które może i powinno być dobrze zorganizowane i zarządzane?

Odpowiedzią na tak postawione pytanie jest m.in. deklaracja z Glasgow ${ }^{2}$ z 2005 r., zatytułowana Silne uniwersytety dla silnej Europy, dokument Europejskiego Stowarzyszenia Uniwersytetów (European University Association), w której czytamy m.in.: „Europa potrzebuje silnych i twórczych uniwersytetów jako głównych aktorów kształtujących europejskie społeczeństwo wiedzy przez umożliwienie szerokiego dostępu do studiów, przez rozwój oferty kształcenia ustawicznego oraz przez promocję jakości i doskonałości w nauczaniu, uczeniu się, badaniach naukowych i działaniach innowacyjnych".

W kontekście wyzwań stawianych przed środowiskiem akademickim istotne są rozważania nad modelem uniwersytetu. Wypracowanie nowego modelu uniwersytetu jest poważnym wyzwaniem dla środowiska akademickiego oraz jego otoczenia/środowiska wewnętrznego i zewnętrznego. Otoczenie uniwersytetu jako organizacji obejmuje całokształt zjawisk, procesów i instytucji kształtujących jego relacje, możliwości rozwoju, zakres działalności i perspektywy rozwojowe. Środowisko wewnętrzne składa się z warunków i sił wewnątrz uniwersytetu. W jego centrum stoją rektor i senat uczelni, a poza nim - pracownicy, doktoranci, studenci, absolwenci oraz kultura całej organizacji.

Środowisko zewnętrzne uniwersytetu określane jest jako otoczenie, wszystko to, co z zewnątrz uczelni może na nią wpływać. Granica dzieląca uniwersytet od otoczenia zewnętrznego nie zawsze jest precyzyjna i wyraźnie określona. Przykładem są podmioty wspierania przedsiębiorczości akademickiej (AIP, parki technologiczne, klastry), które funkcjonalnie są silnie powiązane $\mathrm{z}$ uczelnią, ale w ujęciu organizacyjnym są raczej elementem jej otoczenia. Na otoczenie zewnętrzne składają się system polityczno-prawny, system kulturowy oraz konkurencyjny system międzynarodowy. W strukturze otoczenia zewnętrznego należy wyróżnić otoczenie bliższe uczelni, które obejmuje klientów uczelni (uczniowie szkół średnich, pracownicy przedsiębiorstw), sojuszników strategicznych (uczelnie partnerskie, centra badawczo-rozwojowe, samorządy terytorialne), organizacje społeczne (stowarzyszenia, fundacje), podmioty współpracujące (organizacje pracodawców, banki, przedsiębiorstwa).

\footnotetext{
${ }^{2}$ Deklaracja z Glasgow określa działania, które zapewnią odpowiedni wkład uniwersytetów w budowanie Europy jako głównego aktora na arenie światowej. Ten plan działań jest kontynuacją inicjatyw będących wynikiem decyzji podjętych przez EUA w Salamance (2001) i w Grazu (2003).
} 
Ryc. 1. Uniwersytet przedsiębiorczy/innowacyjny, uniwersytet uczący się

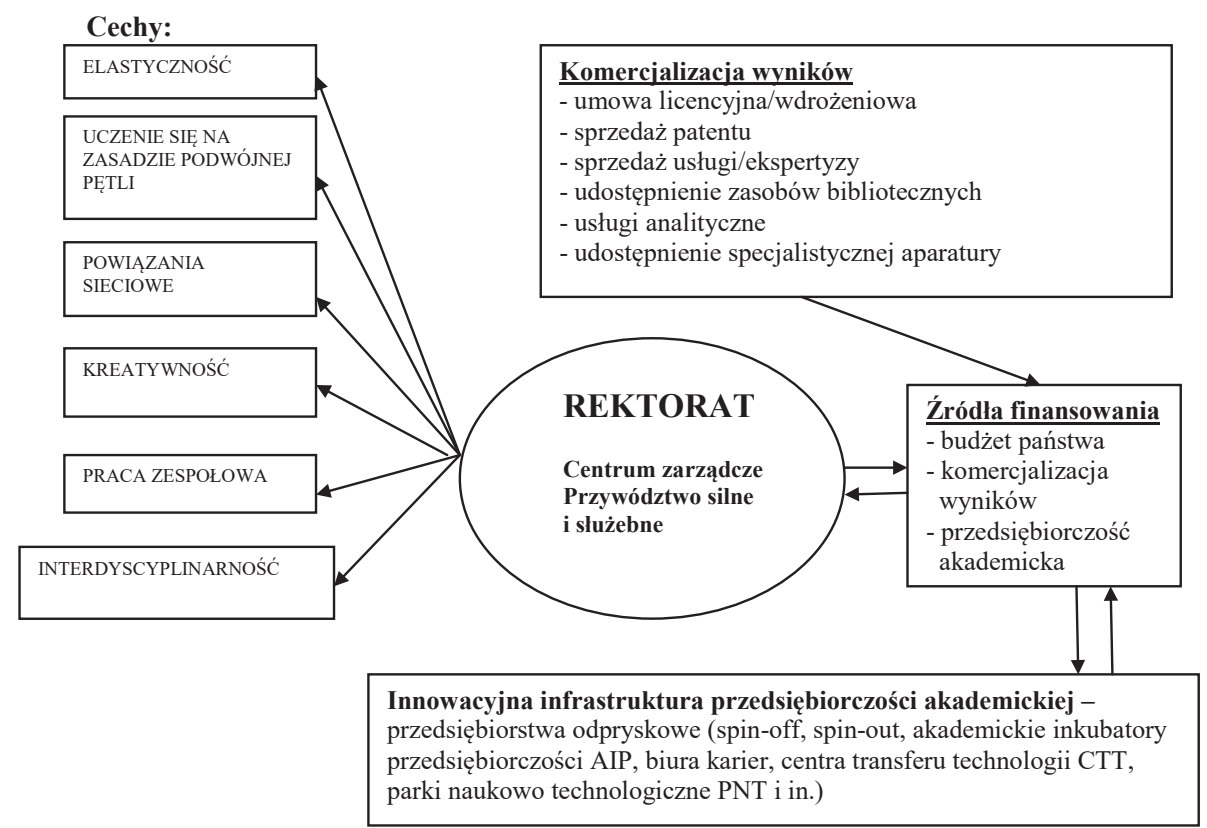

Źródło: opracowanie własne

Najistotniejszym atrybutem uczelni opartej na wiedzy jest silne i służebne wobec społeczności akademickiej centrum zarządcze. Jego zadaniem jest koordynowanie aktywności jednostek będących w strukturze organizacyjnej uczelni, a formą działania powinno być elastyczne podejście do rozwiązywania wszelkich problemów i zapewnienie pracownikom możliwości samoorganizacji, charakterystycznej dla organizacji wiedzy.

\section{Zarządzanie uniwersytetem}

Innowacyjny uniwersytet $\mathrm{w}$ gospodarce opartej na wiedzy buduje swoją przewagę komparatywną przez umiejętność kreowania nowej wiedzy i wspierania jej przepływu oraz zdolność do ustawicznego uczenia się. Ten nowy model uczelni wyższej kształtuje się w odpowiedzi na potrzeby nowego paradygmatu gospodarki opartej na jak najbardziej efektywnym wykorzystaniu wiedzy (Wawak, 2017).

Innowacyjny uniwersytet opiera się na takich elementach, jak:

- korzyści z tworzenia wiedzy i stałego jej ulepszania,

- działalność polegająca na tworzeniu wiedzy (badania podstawowe), połączenie fazy tworzenia wiedzy $\mathrm{z}$ fazą wdrożenia innowacji,

- korzyści wynikające z komercjalizacji wiedzy,

- korzyści wynikające z ustawicznego kształcenia i awansu naukowego pracowników,

- korzyści wynikające ze zorientowania uczelni na potrzeby globalne,

- korzyści wynikające z relacji wzajemnych zależności uczelni w sieci,

- korzyści związane z elastycznym zarządzaniem uczelnią. 
Tak jak wspomniano wyżej, w procesie zarządzania innowacyjną uczelnią decydujące znaczenie ma centrum, czyli rektor i senat. Powinno ono uwzględniać zasady wzmacniające aktywność i elastyczność jednostek organizacyjnych. Do wiodących zasad, których stosowanie jest warunkiem zarządzania innowacyjnym uniwersytetem, należy zasada nadmiarowości (redundacja), interdyscyplinarności, elastyczności, samoorganizacji, samoregulacji i samokontroli (Leja, 2011).

Zasada nadmiarowości wskazuje, że nadmiar zbędnej lub szkodliwej ingerencji/regulacji pracy zespołów (np. zespołów naukowych, pojedynczych pracowników) prowadzi do niecelowego zużycia zasobów, bez możliwości uzyskania racjonalnych efektów, np. przydzielanie zespołom/pracownikom nowych zadań, nowego przedsięwzięcia badawczego, przy którym wymagana jest zmiana ról, kompetencji.

Zasada interdyscyplinarności opiera się na „burzeniu granic między dyscyplinami, a nie na sumowaniu wiedzy. Wyrazem tego jest prowadzenie badań „nad” wybranymi fragmentami otaczającej nas rzeczywistości i ujmowanie ich w perspektywie różnych dyscyplin” (Markowski, 2012).

Zasada elastyczności umożliwia, przy pomocy instrumentów ustawowych oraz instytucjonalnych nieobejmujących wszystkich zespołów/pracowników, wprowadzanie przez centrum zarządcze rozwiązań pogłębiających proces integracji uczelni. Elastyczność zapewnić można za pomocą procedur dotyczących mechanizmów postępowania na wypadek różnych scenariuszy. Elastyczność powinna cechować liderów, którzy wiedząc, że warunki rzeczywiste znacznie różnią się od zaplanowanych, powinni dokonywać relatywnie szybkich i oczekiwanych zmian. Potrzeba elastycznego podejścia do zarządzania uczelnią nie zwalnia centrum zarządczego z procesu ustalania celów i odpowiednich działań, by je osiągnąć.

Zasada samoorganizacji mówi, że menedżerowie powinni być elastyczni oraz powinni ułatwiać samoorganizowanie zespołów, a nie zajmować się ich organizowaniem. W zespole uczelnianym przyjąć też trzeba, że role mogą się zmieniać zależnie od okoliczności. Takie rozwiązania stanowią zerwanie $z$ wzorcem hierarchicznym, a podstawą działania zespołu są dociekania, a nie z góry założony projekt.

Zasada samoregulacji ${ }^{3}$ umożliwia wykorzystanie wiedzy jawnej i ukrytej dla osiągnięcia założonych celów organizacji, zespołów badawczych, pracowników uczelni (Mańka, 2016). W ramach regulatorów wewnętrznych na podstawie konfiguracji informacji (nie tylko regulujących) pozyskiwanych $\mathrm{z}$ otoczenia $\mathrm{w}$ organizacji powinien powstać wewnętrzny system samoregulacji, rozumiany jako wyodrębniony strukturalnie zespół reguł, np. procedur postępowania, umożliwiający przetworzenie każdej informacji w decyzję kierowniczą (Szałucki, 2012).

Zasada samokontroli pozwala na budowanie pozytywnych relacji w zespole, tolerancji, otwartości i merytorycznej dyskusji ${ }^{4}$.

\footnotetext{
${ }^{3}$ Samoregulacją nazywa się umiejętność wykorzystywania wiedzy o prawach rządzących ludzkim zachowaniem do zdobywania celów, których urzeczywistnienie pomoże nam osiągnąć satysfakcję. Jak wiadomo, same intencje w połączeniu z pozytywnym myśleniem są istotnymi fundamentami, lecz niestety, nie są wystarczające, by osiągnąć zamierzony cel. By zrealizować wyznaczone plany, trzeba skupić się przede wszystkim na działaniu, gdyż jedynie jasno sprecyzowane cele pozwolą nam na dążenie do samodoskonalenia i osiągania pożądanych rezultatów.

${ }^{4}$ Z samokontrolą wiążą się interesujące zjawiska. Próby kontroli swoich myśli i uczuć skutkują zwykle narastaniem uczucia presji wewnętrznej na wykonywanie kontrolowanych zachowań i nasilaniem się tłumionych
} 
Innowacyjna infrastruktura przedsiębiorczości akademickiej: start-upy, przedsiębiorstwa spin-off oraz spin-out

Dla rozwoju przedsiębiorczości akademickiej bardzo duże znaczenie ma potencjał innowacyjnych narzędzi przedsiębiorczości akademickiej, nazywanych innowacyjną infrastrukturą przedsiębiorczości akademickiej. Do narzędzi tych zaliczamy: programy i projekty wsparcia oraz instytucjonalne formy wspierania przedsiębiorczości akademickiej, np. przedsiębiorstwa odpryskowe, takie jak spin-off, spin-out, akademickie inkubatory przedsiębiorczości AIP, biura karier, centra transferu technologii CTT, parki naukowo technologiczne PNT i inne (Makieła, 2016).

Geneza przedsiębiorstw odpryskowych spin-off oraz spin-out wiązana jest powszechnie z przedsiębiorczością akademicką, co nie jest jednak ujęciem precyzyjnym (Richert-Kazimierska, 2010). Spin-off, spin-out są także metodą, którą przedsiębiorstwo może wykorzystać do zbycia pewnych aktywów, oddziałów lub filii. Podczas gdy wybór konkretnej metody przez spółkę dominującą zależy od wielu czynników, ostatecznym celem jest zwiększenie wartości dla akcjonariuszy. Istotne znaczenie ma rozróżnienie przedsiębiorstw spin-off od przedsiębiorstw spin-out, ponieważ pozwala to zrozumieć ich istotę oraz koncepcję źródeł przewag konkurencyjnych obu rodzajów podmiotów (Dec, 2011).

Przedsiębiorstwa spin-off to nowe przedsiębiorstwa, założone przez co najmniej jednego pracownika instytucji naukowej lub badawczej, albo studenta bądź absolwenta uniwersytetu w celu komercjalizacji innowacyjnych pomysłów (wiedzy) lub technologii (Dec, 2011). Wśród nich wyróżnia się przedsiębiorstwa powstałe jako jednostki wydzielone z korporacji oraz wydzielone z placówek naukowych (Tamowicz, 2006). Przedsiębiorstwa spin-off są zwykle niezależne osobowo i kapitałowo od swojej uczelni, jednak często z nią współpracują na zasadach rynkowych.

Przedsiębiorstwa typu spin-out to nowe przedsiębiorstwa, które zostały założone przez co najmniej jednego pracownika instytucji naukowej lub badawczej, albo studenta bądź absolwenta uczelni oraz uczelnię lub jednostkę organizacyjną uczelni, powołaną do komercjalizacji dóbr intelektualnych uczelni, w celu komercjalizacji innowacyjnych pomysłów (wiedzy) lub technologii. Przedsiębiorstwa spin-out są zwykle powiązane osobowo i kapitałowo z Uczelnią, co w konsekwencji oznacza bliską współpracę obu stron (Turek, 2016).

Z przytoczonych definicji wynika, że założycielem spółki typu spin-off lub spin-out może być student, absolwent lub pracownik naukowy. Aby spółka założona przez studenta, absolwenta lub pracownika naukowego miała status przedsiębiorstwa spin-off czy spin-out, musi opierać się na własności intelektualnej, która powstała w ścisłym związku z nauką lub pracą założyciela przedsiębiorstwa w uniwersytecie lub jednostce naukowej. W konsekwencji działalność spin-off i spin-out ma najczęściej charakter innowacyjny, gdyż jej głównym celem jest wdrożenie w praktyce gospodarczej efektów prac badawczo-rozwojowych prowadzonych na uczelni (lub innej jednostce naukowej) (Dec, 2016). Wynika $\mathrm{z}$ tego, że przedsiębiorstwa spin-off oraz spin-out wyróżnia podmiot ją zakładający (pracownik naukowy, student lub absolwent uniwersytetu), a także to, że korzystają z dóbr intelektualnych uniwersytetu, które powinny stanowić o przewadze konkurencyjnej.

myśli. Tak dzieje się przede wszystkim w początkowych etapach wprowadzenia kontroli. Zjawisko to nazywane jest paradoksalnym efektem kontroli. 
Istotnym czynnikiem różnicującym oba typy przedsiębiorstw jest związek, jaki mają one ze swoimi organizacjami macierzystymi. „W Dolinie Krzemowej panuje opinia, że jeśli nie wiesz, co chcesz sprzedawać, komu, za ile i jakimi kanałami, to znaczy, że jesteś start-upem. Nie jest to szczególnie wysoko zawieszona poprzeczka, więc nie powinno dziwić, że pojęcia startupu używamy (i nadużywamy) właściwie codziennie” (Giełzak, 2016: 39).

Start-upy kojarzą się z innowacyjnością akademicką, jeśli jednak nie tworzą unikalnej wartości, nie działają w warunkach skrajnej niepewności, stają się przeważnie zwykłymi przedsiębiorstwami. Panuje przekonanie, że start-upy są przedsiębiorstwami należącymi do kolejnej fazy rewolucji przemysłowej, rewolucji cyfrowej, gospodarki opartej na wiedzy. Głównym motywem decydującym o powstaniu tych przedsiębiorstw lub pracy w nich jest odmienna od korporacji kultura organizacyjna. Kultura organizacyjna start-upu to także osobiste priorytety, normy i wartości, jasne zasady okazywane na zewnątrz i wewnątrz startupu. Zarządzanie start-upem to angażowanie do działania swoich pracowników, klientów i dostawców. Należy pamiętać, że ludzie chętniej podążają za tym, co robisz, a nie za tym, co mówisz.

Kultura organizacyjna przedsiębiorstwa ma ogromny wpływ na sposób zarządzania i kształtuje zachowanie pracowników w przedsiębiorstwie. Powinna ona wspierać organizację w osiąganiu celów, a nie stawać się źródłem przeszkód i barier w dalszym rozwoju. Rozwijając start-up, warto zastanowić się, jaką kulturę organizacyjną chcemy tworzyć i jakimi wartościami będziemy kierować się w przyszłości.

Źródła finansowania przedsiębiorczości akademickiej

„Procesy finansowania działalności gospodarczej można rozpatrywać na wielu płaszczyznach, w zależności od przyjętych kryteriów. Nie ma uniwersalnego sposobu finansowania przedsiębiorstwa, jaki można by zalecić w każdej sytuacji. Potrzeby finansowe uzależnione są od skali aktywności działalności gospodarczej, jak i również od wielkości popytu na jego produkty i usługi. Podjęcie decyzji o wyborze rodzaju finansowania powinno być poprzedzone właściwą analizą, biorącą pod uwagę korzyści i koszty oraz ryzyko i termin, w którym otrzymany zostanie kapitał. Dokonując wyboru, powinniśmy kierować się przede wszystkim celem, którego realizacji będą służyć uzyskane środki finansowe, a także możliwościami, które firma ma na danym etapie rozwoju.

Według tradycyjnego podziału wyróżniamy zewnętrzne i wewnętrzne źródła finansowania działalności. Większość przedsiębiorców, szczególnie tych zaczynających działalność gospodarczą, ogranicza się do zasobów własnych oraz kredytów bankowych. Mało rozpowszechnione są możliwości pozyskania środków finansowych w formie venture capital czy pomocy aniołów biznesu. Wymienić należy również Program Operacyjny Innowacyjna Gospodarka, którego głównym celem jest rozwój polskiej gospodarki w oparciu o innowacyjne przedsiębiorstwa. Osiągnięcie tego celu jest możliwe przez inwestowanie w sferę badawczo-rozwojową $(\mathrm{B}+\mathrm{R})$ oraz wdrażanie innowacji. Obecnie więcej uwagi poświęca się również start-upom" (Strużycki, 2002: 232-235).

Kapitał własny ze względu na źródło pochodzenia dzielimy na kapitał wewnętrzny i zewnętrzny. Kapitał wewnętrzny tworzą: zysk netto, amortyzacja, przekształcenia w majątku oraz przekształcenia w kapitałach. Natomiast na kapitał zewnętrzny składają się: dopłaty wspólników, poszukiwanie nowych wspólników, fundusze venture capital i emisja na rynku pozagiełdowym. 
Do kapitału obcego zaliczamy: kapitał długoterminowy (rezerwy, bankowe kredyty długoterminowe, poręczenia kredytowe, leasing, franchising, obligacje, dotacje i subwencje, środki z funduszy pomocowych), kapitał krótkoterminowy (bankowe kredyty krótkoterminowe, zobowiązania odnawialne, kredyt od dostawców, kredyty od odbiorców, faktoring, pożyczki z sektora pozabankowego oraz krótkoterminowe papiery dłużne) (Strużycki, 2002: 235).

W Polsce do najpopularniejszych źródeł kapitału należą środki własne (79\%), dotacje UE (24\%) i fundusze VC (22\%). Interesujący jest także fakt, że połowa wszystkich startupów korzysta wyłącznie ze środków własnych. Takie przedsiębiorstwa określane są mianem bootstraperów ${ }^{5}$.

Wybierając strategię finansowania startupów, musimy brać pod uwagę nie tylko wady i zalety poszczególnych źródeł kapitału, ale również dopasowanie tych źródeł do fazy rozwoju firmy.

\section{Pre-seed - najwcześniejszy etap}

Najwcześniejszą fazą rozwoju start-upa jest faza pre-seed, związana z inicjacją pomysłu na biznes i wstępnym przygotowaniem do jego realizacji. Na tym etapie powstają wstępne koncepcje produktu, wyprzedzające stworzenie prototypu. Pierwsza faza życia start-upu wymaga umiarkowanie wysokiego, ale stałego zasilania kapitałem. Problem w tym, że na tak wczesnym etapie nie znajdziemy zbyt wielu chętnych oferentów kapitału. Przedsiębiorstwo musi szukać pieniędzy tam, gdzie są, u tych, którzy są gotowi nam zaufać, czyli tzw. FFF - Family, Friends, Fools ${ }^{6}$. W ten sposób określamy tych, którzy bardziej chcą pomóc, niż zarobić i nie będą pytać o rentowność czy możliwości wyjścia $\mathrm{z}$ inwestycji. Finansowanie tego etapu jest obciążone bardzo wysokim ryzykiem, w niektórych przypadkach zwrot $\mathrm{z}$ inwestycji jest możliwy po 5-7 latach, a w niestabilnej sytuacji finansowej na rynku - nawet po 10 latach. Inaczej jest w przypadku akceleratorów biznesu $^{7}, \mathrm{z}$ założenia nastawionych na dłuższy okres mentoringu i dojrzewania biznesu, zanim osiągnie on skalowalność i wejdzie na ścieżkę szybkiego rozwoju. Ciekawą alternatywę dla finansowania tego etapu rozwoju start-upów może stanowić crowdfunding ${ }^{8}$, który staje się nowym źródłem wspomagania przedsiębiorczości akademickiej.

${ }^{5}$ Dosłownie: 'tych, które się podciągają za własne sznurowadła'. Jest to możliwe dzięki temu, że opierają się one głównie na darmowej pracy swoich założycieli. Potwierdzają to najpopularniejsze w tej grupie wskaźniki zatrudnienia: między jedną osobą a trzema osobami. Ich poświęcenie bywa opłacalne: start-upy korzystające wyłącznie ze środków własnych szybciej niż pozostałe osiągają regularne przychody. Potwierdza to regułę, że bootstraperzy ostrożniej podchodzą do wydatków stałych (np. wynagrodzenia) oraz szybciej generują zysk, bo innych alternatyw, aby podtrzymać działalność firmy, po prostu nie mają.

${ }^{6}$ Friends, Family, Founds (FFF) - środki własne, rodziny czy przyjaciół.

${ }^{7}$ Akceleratory biznesu to innymi słowy programy mające wspierać biznes w sposób podobny do inkubatorów przedsiębiorczości. Dzięki nim można liczyć na wielopłaszczyznowe wsparcie przy zakładaniu własnych firm, a także w ich prowadzeniu. Przede wszystkim zakładają one pomoc w postaci przekazania wiedzy merytorycznej, ale też pomoc prawną i organizacyjną. Niestety, zarówno w Polsce, jak i w innych europejskich krajach akceleratory biznesu są jeszcze dość mało popularne. Zdecydowanie większą sławę zyskały w Stanach Zjednoczonych, gdzie to właśnie one pomogły w założeniu kilku, prężnie dziś działających firm. Największym akceleratorem biznesu na świecie jest Y Combinator.

${ }^{8}$ Crowdfunding - forma finansowania różnego rodzaju projektów przez społeczność, która jest lub zostanie wokół tych projektów zorganizowana. Przedsięwzięcie jest w takim przypadku finansowane przez dużą liczbę drobnych, jednorazowych wpłat dokonywanych przez osoby zainteresowane projektem. Upowszechnienie 


\section{Seed - etap drugi}

$\mathrm{Na}$ drugim etapie (seed) rozwoju start-up ma już prototyp własnego produktu lub nawet zaczął oferować gotowy produkt na rynku. Nakłady przedsiębiorstwa zwiększają się, własnych środków już nie wystarcza, a rozpoczęta działalność operacyjna wymaga zewnętrznego finansowania. W tej fazie start-up jeszcze nie przekroczył progu rentowności, a ewentualny zysk jest w całości reinwestowany. Duże ryzyko operacyjne oraz brak zyskowności zniechęcają inwestorów do finansowania start-upów, dlatego praktycznie niemożliwe jest zaciągnięcie kredytów lub pożyczek na tym etapie. Zatem pozyskiwane pieniądze, również w tej fazie, będą głównie pochodziły z kapitału własnego.

$\mathrm{Na}$ tym etapie start-up ma największe szanse na pozyskanie finansowania ze strony aniołów biznesu ${ }^{9}$ oraz $\mathrm{z}$ funduszy zalążkowych ${ }^{10}$. Jeżeli przedsiębiorstwu nie udało się dostać wsparcia w fazie pre-seed, to na etapie seedu prawdopodobieństwo sukcesu jest znacznie większe, dlatego że indywidualni inwestorzy oraz fundusze mogą zobaczyć nie tylko samą ideę projektu, ale też już gotowy produkt i pierwsze wyniki działalności przedsiębiorstwa.

\section{Early Stage - etap trzeci (wczesnego wzrostu)}

$\mathrm{Na}$ etapie wczesnego wzrostu start-up nadal charakteryzuje się bardzo wysokim ryzykiem operacyjnym, ale już zaczyna zwiększać rentowność sprzedaży. Przedsiębiorstwo umacnia własną pozycję na rynku i ma przesłanki do dalszej ekspansji. W związku ze zwiększeniem nakładów na rozwój przedsiębiorstwo nadal pozyskuje środki finansowe ze źródeł zewnętrznych, ponieważ przy niskiej rentowności nie jest w stanie się samofinansować.

Do dostępnych źródeł kapitału na tym etapie już zaliczają się m.in. banki komercyjne, jednak podchodzą one do finansowania start-upów we wczesnej fazie ze zwiększoną ostrożnością i wliczają ponoszone wysokie ryzyko w cenę kredytu. Kapitał obcy na tym etapie nadal jest bardzo drogim i mało dostępnym środkiem finansowania działalności

się internetu pozwala na łatwe informowanie o projektach i tworzenie wokół nich społeczności, co przyczyniło się do rozwoju zjawiska crowdfundingu. Określenie to jest zwykle używane w odniesieniu do zbiórek prowadzonych na stworzonych w tym celu platformach internetowych, rzadziej także przy pomocy serwisów społecznościowych lub blogów.

${ }^{9}$ Anioł biznesu to prywatny inwestor, który dysponując odpowiednim doświadczeniem oraz kapitałem, wspiera wybrane małe i średnie przedsiębiorstwa zarówno merytorycznie, jak i finansowo, głównie w początkowej fazie ich rozwoju (start-up). Często inwestuje w te obszary, w które inni obawiają się wkraczać, oczekując w zamian udziałów w firmie i wpływu na strategiczne decyzje. Niektórzy inwestorzy działają też na zasadach non profit, dążąc jednocześnie do wspierania możliwie najlepszych biznesowo projektów. Aniołowie biznesu są najstarszym, największym i najczęściej używanym źródłem zewnętrznego finansowania przedsiębiorczości.

${ }^{10}$ Fundusz zalążkowy (fundusz inkubacyjny; ang. seed-money lub seed capital) to rodzaj inwestycji Capital Venture. Jako kategoria private equity, jest jednym z możliwych źródeł kapitału użytecznego dla przedsiębiorstw nienotowanych na giełdzie papierów wartościowych mających potrzebę uzyskania dodatkowego dofinansowania. Działalność funduszy kapitału zalążkowego jest możliwa dzięki zasileniu kapitałowemu ze środków unijnych. Fundusze kapitału zalążkowego to ciekawa propozycja dla początkujących firm. Maksymalna wysokość dotacji dla pojedynczego przedsiębiorcy to aż 200 tys. euro! Żeby sięgnąć po te środki, wystarczy właściwie tylko dobry pomysł na biznes. Fundusz pomoże założyć firmę, opracować biznesplan i strategię działania, udostępni lokal na siedzibę i oczywiście - dofinansuje rozwój nowego produktu lub usługi. W zamian obejmie nie więcej niż 50\% udziałów. Fundusze dysponują obecnie łącznym budżetem prawie $500 \mathrm{mln}$ zł. 
start-upu. Oprócz aniołów biznesu i funduszy zalążkowych o wsparcie finansowe w tej fazie można ubiegać się z funduszy Venture Capital.

\section{Expansion i Late Stage - etap czwarty (ekspansja i stabilizacja)}

Na etapie ekspansji i stabilizacji start-up cechuje się sprawdzonym modelem biznesowym i wysoką rentownością. Łatwiej jest wtedy pozyskać kapitał na dalszy rozwój, ponieważ ryzyko operacyjne i inwestycyjne zmniejszyło się. Finansowanie przestaje pochodzić w większym stopniu z kapitału własnego, gdyż kapitał obcy staje się bardziej dostępny. Na tych etapach dominuje finansowanie z kredytów bankowych i dłużnego kapitału pozabankowego oraz funduszy Venture Capital i Private Equity ${ }^{11}$.

Istotnymi instytucjami wsparcia start-upów są w Polsce instytucje otoczenia biznesu. Polski system instytucji otoczenia biznesu jest bogaty zarówno ze względu na liczbę instytucji, jak i ze względu na ich różnorodność. Wyróżnia się trzy główne grupy wspomnianych instytucji:

- ośrodki przedsiębiorczości - ich działalność to szeroka promocja i inkubacja przedsiębiorczości (często w grupach dyskryminowanych), dostarczanie usług wsparcia do małych firm i aktywizacja rozwoju regionów peryferyjnych lub dotkniętych kryzysem strukturalnym;

- ośrodki innowacji - zajmują się szeroką promocją i inkubacją innowacyjnej przedsiębiorczości, transferem technologii i dostarczaniem usług proinnowacyjnych, aktywizacją przedsiębiorczości akademickiej i współpracy nauki z biznesem;

- instytucje finansowe - ułatwiają dostęp do finansowania działalności nowo powstałych oraz małych firm bez historii kredytowej, a także zajmują się dostarczaniem usług finansowych dostosowanych do specyfiki innowacyjnych przedsięwzięć gospodarczych.

\section{Zakończenie}

Przedsiębiorczy, innowacyjny uniwersytet wymaga nowego modelu zarządzania, którego celem jest skuteczna współpraca $\mathrm{z}$ otoczeniem krajowym i międzynarodowym. To uczelnia, w której badania naukowe spełniają warunki komercjalizacji, pracownicy nauki, studenci, absolwenci są zmotywowani do podejmowania wyzwań konkurencyjnych, a przedsiębiorczość jest elementem kultury akademickiej.

Silne centrum zarządcze uniwersytetu powinno być elastyczne na inicjatywy oddolne, wzmacniać powiązania sieciowe podmiotów uniwersytetu z otoczeniem, wspierać zarządzanie poziome przez uczenie się na zasadzie podwójnej pętli, powinno być też otwarte na nowe formy organizacyjne. Zmienić powinno się postrzeganie roli centrum jako administratora zasobów uniwersytetu w kierunku podejścia menedżerskiego.

Sugerowane zmiany zarządzania uniwersytetem mają prowadzić do wzmocnienia postaw przedsiębiorczych i innowacyjnych pracowników, studentów i absolwentów,

\footnotetext{
${ }^{11}$ Private equity - szczególny rodzaj inwestycji kapitałowych stanowiących zewnętrzne źródło finansowania spółek niedopuszczonych do obrotu publicznego. Środki przekazywane spółkom mogą mieć charakter zarówno finansowania własnego, jak i hybrydowego, tj. połączenia finansowania własnego i dłużnego. Poza wkładem finansowym w ramach private equity spółka może otrzymać od inwestora wsparcie w zakresie zarządzania o różnorodnym charakterze (np. doradztwo prawne, podatkowe, organizacyjne).
} 
uczynienia z postaw przedsiębiorczych obyczaju akademickiego. Dla realizacji tych zamierzeń koniecznym jest wzmocnienie potencjału innowacyjnych narzędzi przedsiębiorczości akademickiej, nazywanych innowacyjną infrastrukturą przedsiębiorczości akademickiej, do której zaliczamy programy i projekty wsparcia, instytucjonalne formy wspierania przedsiębiorczości akademickiej, np. przedsiębiorstwa odpryskowe (spin-off, spin-out, akademickie inkubatory przedsiębiorczości AIP, biura karier, centra transferu technologii CTT, parki naukowo technologiczne PNT i in.)

Przedsiębiorczy i innowacyjny uniwersytet powinien cechować się wskaźnikami określającymi poziom innowacyjności. Zaliczają się do nich m.in.: liczba patentów zarejestrowanych w Światowej Organizacji Własności Intelektualnej, stosunek zgłoszeń patentowych do dotacji, odsetek patentów o zasięgu międzynarodowym, całkowita liczba cytowań związanych z patentami, wskaźnik analizy wpływu patentu na dalszy rozwój badań, łączna liczba artykułów naukowych dotyczących wynalazków, liczba artykułów opracowanych przez naukowców z danej uczelni we współpracy z przemysłem.

\section{Literatura}

\section{References}

Andrzejczak, A. (2015). Uniwersytet przedsiębiorczy i odpowiedzialny społecznie. Edukacja Ekonomistów i Menadżerów, 4(38).

Clark, B.R. (1998). Creating Entrepreneurial Universities: Organizational Pathways of Transformation. Oxford: Pergamon, For IAU Press.

Dec, D. (2011). Firmy typu spin-off i spin-out. Poradnik dla osób chcących założyć działalność gospodarcza. Szczecin.

Dec, D. (2016, 1 listopada). Od pomystu do zysku - czyli spin-off/spin-out w teorii i praktyce. Pozyskano z: http://webcache.googleusercontent.com/search?q=cache:9SWGhbbtkPwJ:kreatywnyprzedsiebiorca.vizja.pl/pl/pobierz-plik/id/13+\&cd=1\&hl=pl\&ct=clnk\&gl=pl\&client=firefox-b-ab

Dudzikowa, M. (2012). Sytuacja problematyczna interdyscyplinarności w naukach społecznych i humanistycznych (z kryzysem w tle). W: A. Chmielewski, M. Dudzikowa, A. Grobler (red.), Interdyscyplinarnie o interdyscyplinarności. Między idea a praktyką. Kraków: Impuls, 15-38.

Enders, J., Musselin, CH. (2008). Back to the future? the academic professions in the 21 st century, OECD: Higher Education to 2030, Vol. 1: Demography.

Giełzak, M. (2016, 1 listopada). Źródła finansowania startupów. Pozyskano z: http://mamstartup.pl/inwestycje/9793/zrodla-finansowania-startupow-wprowadzenie.

Leja, K. (2011). Koncepcje zarządzania wspótczesnym uniwersytetem. Gdańsk: Wydawnictwo Politechniki Gdańskiej.

Mańka, M. (2016, 18 października). Samoregulacja motywacji. Pozyskano z: http://www.treco.pl/ wiedza/artykuly-szczegoly/id/706/page/75/samoregulacja motywacji/

Makieła, Z. (2016). The Network Structure: the Menegement Infrastructure of an Innovative City and Region. W: J. Kaczmarek, K. Żmija (red.), Expectations and Challenges of Modern Economy and Enterprises. Problems-Concepts-Actvities. Cracow: Cracow University of Economics, Fundation of the Cracow University of Economics.

Makieła, Z. (2016). Instrumenty wsparcia przedsiębiorczości akademickiej. W: J. Kaczmarek, P. Litwa (red.), Procesy rozwoju przedsiębiortsw w konkurencyjnym i innowacyjnym otoczeniu. Kraków: Uniwersytet Ekonomiczny w Krakowie, Fundacja Uniwersytetu Ekonomicznego.

Markowski, M.P. (1997). Efekt inskrypcji. Jacques Derrika i literatura. Bydgoszcz: Wydawnictwo Homini. Poznańska, K. (2014). Przedsiębiorczość akademicka - cechy i znaczenie w gospodarce światowej i polskiej. W: T. Kraśnicka (red.), Innowacyjność wspótczesnych organizacji. Kierunki i wyniki badań, część II. Katowice: Uniwersytet Ekonomiczny w Katowicach. 
Richert-Kazimierska, A. (2010). Instytucjonalne formy wsparcia przedsiębiorczości akademickiej w Polsce. eMentor, 3(35).

Strużycki, M., (2002). (red.). Zarządzanie małym i średnim przedsiębiorstwem. Uwarunkowania europejskie. Warszawa: Wydawnictwo Diffin.

Szałucki, K. (2012). Przedsiębiorstwa transportowe. Warunki i mechanizmy równowagi. Gdańsk: Wydawnictwo Uniwersytetu Gdańskiego.

Tamowicz, P. (2006). Przedsiębiorczość akademicka: spółki spin-offw Polsce. Warszawa: Agencja Rozwoju Przedsiębiorczości.

Turek, A. (2016, 1 listopada). Jak sprzedać patent $i$ dobrze zarobić. Pozyskano z: http://innpoland. $\mathrm{pl} / 113887$,problemy-zpatentami

Wawak, T. (2012). Jakość zarządzania w szkołach wyższych. Kraków: Wydawnictwo Uniwersytetu Jagiellońskiego.

Wawak, T. (2017). Zarządzanie w szkołach wyższych i innowacje w gospodarce. Kraków: Wydawnictwo Uniwersytetu Jagiellońskiego.

Wisseman, J.G. (2005). Technostarterzy - dlaczego i jak. Warszawa: PARP.

Zbigniew Makieła, prof. dr hab., Uniwersytet Jagielloński, Wydział Zarządzania i Komunikacji Społecznej, Instytut Ekonomii, Finansów i Zarządzania, Katedra Organizacji i Zarządzania. Profesor nauk ekonomicznych - Uniwersytet Ekonomiczny w Krakowie, dr hc Tarnopolskiego Instytutu Społecznych i Informacyjnych Technologii, kierownik Katedry Organizacji i Zarządzania, przewodniczący Rady Instytutu Ekonomii, Finansów i Zarządzania, absolwent Uniwersytetu Pedagogicznego w Krakowie. Autor kilkunastu książek i ponad 180 zwartych artykułów naukowych. Specjalizuje się w zakresie przedsiębiorczości i zarządzania innowacjami, gospodarka przestrzenna. Odznaczenia: Medal Komisji Edukacji Narodowej i Złoty Krzyż Zasługi. Wyróżnienia: 4 Nagrody Ministra Nauki i Szkolnictwa Wyższego, w latach 2007-2011. Rektor Państwowej Wyższej Szkoły Techniczno Ekonomicznej im. Ks. B. Markiewicza w Jarosławiu. Odbył staż naukowy w Harward Uniwersity Extension School.

Zbigniew Makieła, prof. dr hab., Jagiellonian University in Kraków, Faculty of Management and Social Communication, Institute of Economics, Finance and Management, Department of Organization and Management. Professor of economics - Cracow University of Economics, Dr h.c. Ternopil Institute for Social and Information Technology. Employed at the Jagiellonian University in Kraków, Faculty of Management and Social Communication, Institute of Economics, Finance and Management, Department of Organization and Management, graduated from the Pedagogical University of Cracow. The author of several books and more than 180 articles. Specialises in the field of entrepreneurship and innovation management, spatial economy. He was awarded with: Medal of the National Education Commission, Gold Cross of Merit, 4 awards of the Minister of Science and Higher Education, in the years 2007-2011. Rector of the B. Markiewicz State Higher School of Technology and Economics in Jarosław. He took part in an internship organised by the University of Harvard Extension School, session Executive Speaker Training taught by faculty from the Harvard Extension School as part of the program on Management of Higher Education Institutions (January/February 2010).

\section{Adres/Address:}

Uniwersytet Jagielloński

Wydział Zarządzania i Komunikacji Społecznej

Instytut Ekonomii, Finansów i Zarządzania

Katedra Organizacji i Zarządzania

ul. prof. Stanisława Łojasiewicza 4

30-348 Kraków, Polska

e-mail: zbigniew.makiela@uj.edu.pl 